木造家屋の被害分布より推定した

1948年福井地震の震源近傍における地震動強さ

\title{
NEAR-FIELD GROUND MOTION INTENSITY ESTIMATED FROM DAMAGE DISTRIBUTION OF WOODEN HOUSES DURING THE 1948 FUKUI EARTHQUAKE
}

\author{
野畑 有秀*1, 翠川三 郎*2 \\ Arihide NOBATA and Saburoh MIDORIKAWA
}

\begin{abstract}
Evaluation of near-field ground motion is one of the most important issues in the seismic design. In this study, the ground motion intensity of the 1948 Fukui earthquake which is one of the most disastrous in-land shallow earthquakes is investigated, in order to make a better understanding of the characteristic of the near-field ground motion. First, the fragility curve of collapse of wooden houses is built based on the intensity of ground motion estimated from the damage data and the re-evaluated collapse rate of houses. And, the distribution map of ground motion intensity during the 1948 Fukui earthquake is obtained by using this fragility curve. As the result, the estimated peak ground velocity is more than $120 \mathrm{~cm} / \mathrm{s}$ in the central Fukui plane, and partially it exceeds $200 \mathrm{~cm} / \mathrm{s}$.
\end{abstract}

keywords : $\quad$ near-field ground motion, the 1948 Fukui earthquake, peak ground velocity, fragility curve 震源近傍地震動, 1948 年福井地震, 最大速度, 被害関数

\section{1. はじめに}

1995 年兵庫県南部地震以降, 内陸で発生するいわゆる都市直下地震 による地震動の評価が重要になっている。過去の内陸地震のうちで, 1948 年福井地震は福井平野の直下に震源を有し, 内陸地霞の地震動 の特徵を検討する際の重要な地震の一つと考えられる。福井地震では 震源近傍での強震記録は無いが, 近年では; 強震動シミュレーション 手法を用いて, 地震動の再現も行われている 1。しかし, その妥当性 の検討は十分とはいえない。

1948 年福井地震においては, 地震直後に様々な被害調査がなされ, 震源近傍での地震動強さの手がかり峢えば 2) 3) として, 墓石転倒震度, 木造家屋全壊率分布図等が得られている。野畑・翠川 ${ }^{4)}$ は, これらの 被害データを見直し, 墓石転倒調査及び構造物の滑りなどの被害資料 より, '福井平野の各領域に関して, 合震度 (墓石転倒震度) のみなら ず，最大速度の推定も行っている。図 1 (a)に，合震度の推定位置と その值を, 図 1(b)に最大速度の推定位置と推定值を示す。図 $\mathrm{l}^{\prime}(\mathrm{b})$ に 示される最大地動速度の数值は, 墓石の形状に基づき推定した最大地 動速度の範囲を示している。さらに, 福井平野内を領域で分け, 図 1 (b) の㵊大速度を基に, 墓石転倒率や他の被害テータの推定値とを参 考に評価した最大速度の分布を図 2 に示す。その結果によれば, : 福井 平野東縁部では $150 \mathrm{~cm} / \mathrm{s}$ 程度ないしそれ以上, 平野中央部では $120 \mathrm{~cm} / \mathrm{s}$ 以上, 平野南縁部や西縁部および福井市内では $100 \mathrm{~cm} / \mathrm{s}$ 程度,
平野北西縁部では $100 \mathrm{~cm} / \mathrm{s}$ を下回る值であることが推定されている。 しかしながら，限られた地点での推定であるため, 福井平野における 面的な地震動強さの評価は，同図に示されるように概略的な傾向を示 したのみに留まっている。

一方, 野畑・宮村 ${ }^{51}$ は, 福井地震の木造家屋の被害分布図に ついて, 基となうた統計資料に立ち戻って, 福井平野内の木造家屋全 壊率の再評価を行っている。構造的被害調查に基づく部落数は限られ ているため, 村役場等の被害調査や福井市内の調査に基づく全壊率を 構造的全壊率に補正し, 福井地震における木造家屋全壊率を推定し直 している。図 3 に推定した部落の位置とその全壊率を示す。

本論文は，震源近傍における地震動強さの評価に資することを目的 とし, 限られた地点からの概略的な推定であった図 2 の福井地霞の地 震動強さの分布 ${ }^{4)}$ を改善すべく, 被害地点での, 地震動の強さを推定 した結果 ${ }^{4)}$ と, 統一された指標に補正した福井平野内の木造家屋の全 壊率 ${ }^{5)}$ とを被害関数で関係づけ，平野内全域に存在する木造家屋の被 害データから福井地震の震源近傍での地震動強さの面的な分布をより 詳細に推定することを試みたものである。

\section{2. 木造家屋全壊率と地震動強さの関係}

木造家屋の全壊率と地震動強さの関係は，古くは, 物部 ${ }^{6)}$ により, いわゆる被害関数として正規確率の累積分布関数として表現され，そ
${ }^{* 1}$ 大林組技術研究所 主任研究員 $\cdot$ 博士 (工学)

*2 東京工業大学大学院総合理工学研究科人間環境システム専攻 教授. I. 博
Chief Research Engineer, Obayashi Corporation Technical Research Institute, Dr. Eng.

Prof., Dept. of Built Environment, Interdisciplinary Graduate School of Science and Engineering, Tokyo Institute of Technology, Dr. Eng. 


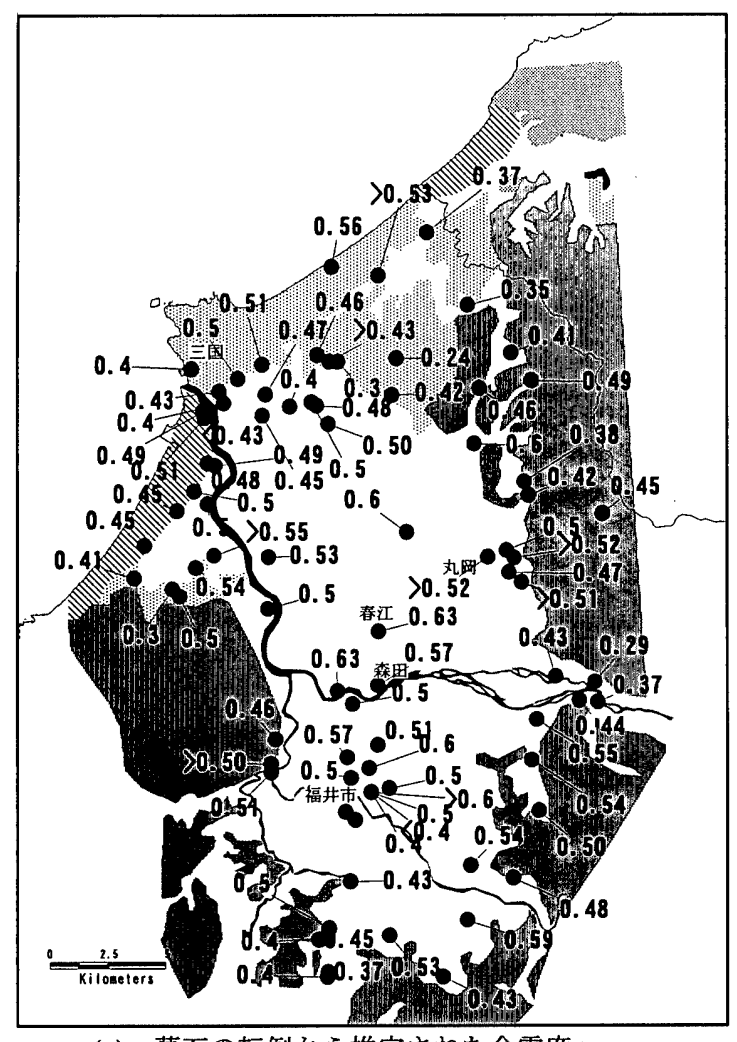

(a) 墓石の転倒から推定された合震度

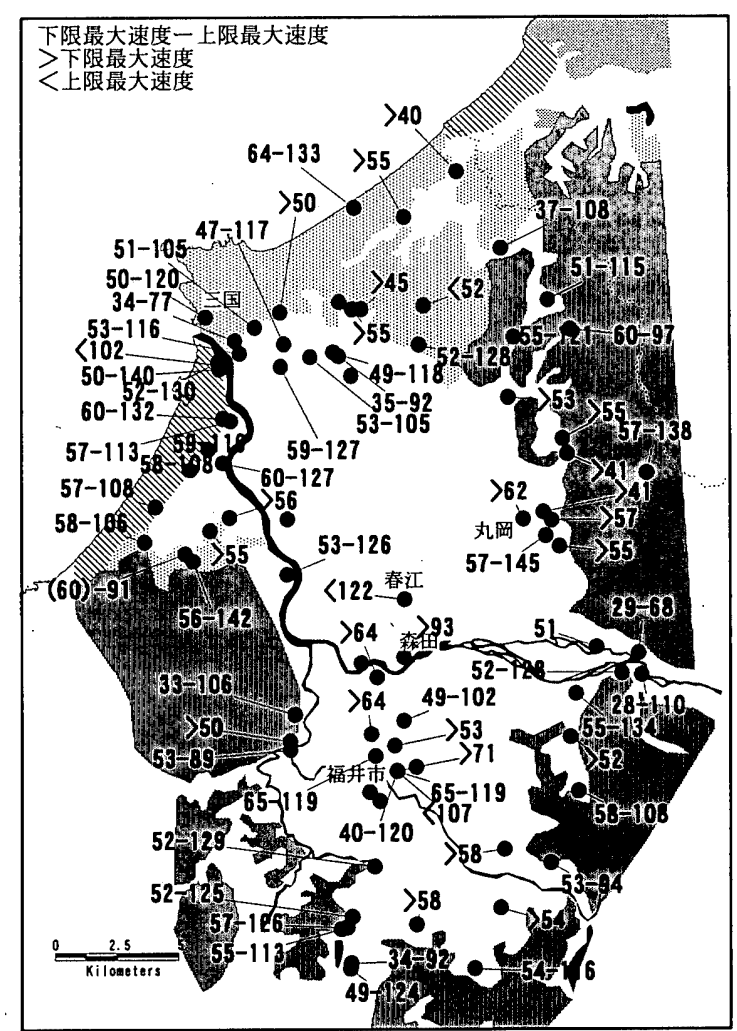

(b) 墓石の転倒から推定された最大地動速度の範囲 図 1 被害関数の算定に用いた地震動強さ ${ }^{4)}$

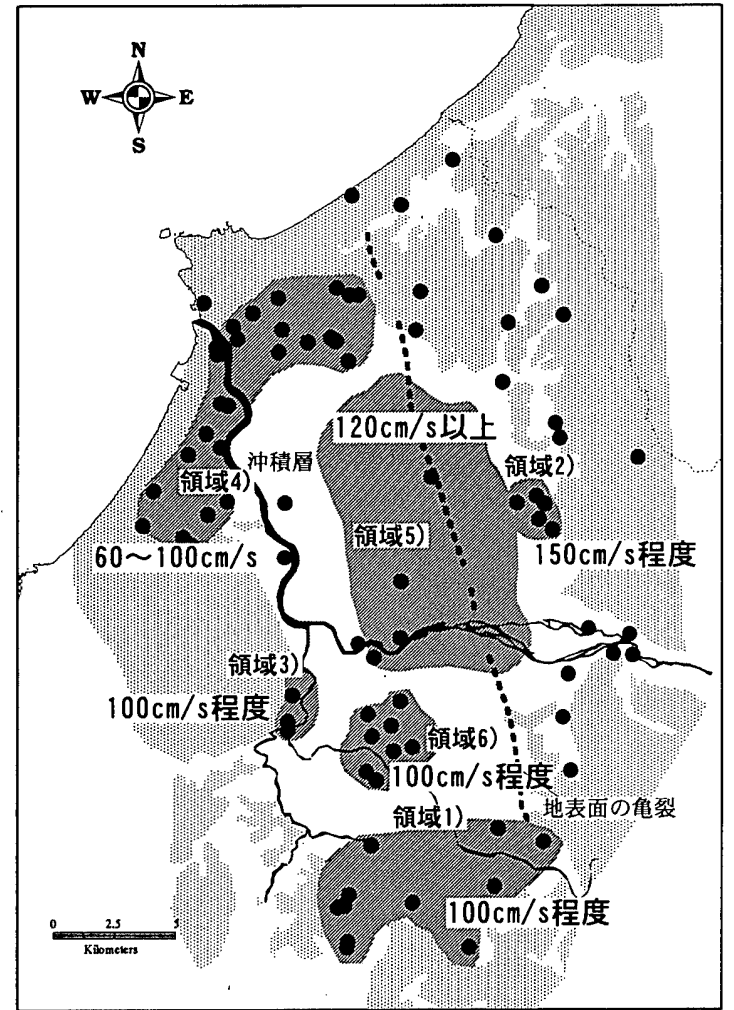

図 2 福井平野内の領域毎の地動最大速度推定値 ${ }^{4)}$

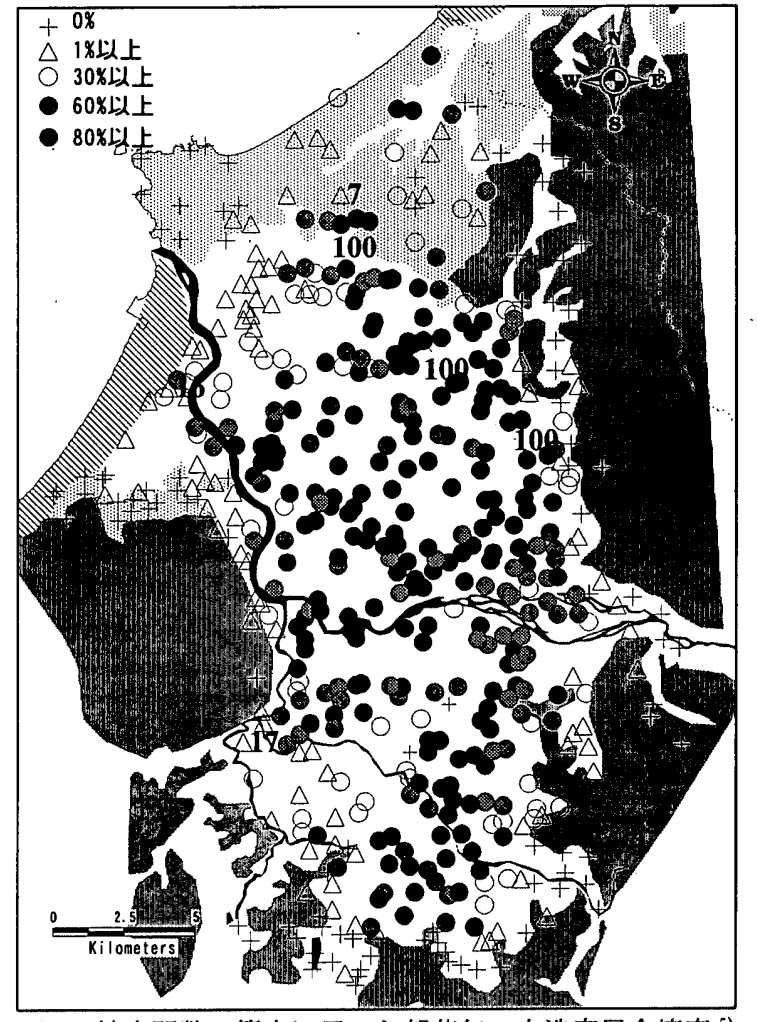

図 3 被害関数の算定に用いた部落毎の木造家屋全壊率 5)

合震度 $\mathrm{K}$ （墓石の転倒震度）との関倸が正規分布により評価されてい る。 


$$
P(K)=\frac{h}{\sqrt{\pi}} \int_{0}^{K} e^{-h^{2}\left(K^{c}-K_{0}\right)^{2}} d K
$$

ここで， $K_{0}$ は，木造家屋の標準的な耐霞力（木造家屋の全壊率が $50 \%$ となる合震度)， $h$ は其の地方の家屋耐震力の一様さを示す指数 であり, 統計論で用いる標準偏差 $\sigma$ とは $\sigma=1 /(\sqrt{2} h)$ の関係となる。

一方, 最大地動速度と木造家屋全壊率の関係については, 福井地震 では検討されてはいない。近年, 兵庫県南部地震の被害から, 多数の 検討甽元ば.9) 10)がなされており, 対数正規分布により, 最大地動速度 V との関倸がもとめられている。

$$
P(V)=\frac{1}{\sqrt{2 \pi} \sigma} \int_{0}^{V} e^{-\left(\operatorname{Ln}\left(V^{\prime}\right)-\operatorname{Ln}\left(V_{0}\right)\right)^{2} / 2 \sigma^{2}} d V^{\prime}
$$

ここで， $V_{0}$ は全壊率が $50 \%$ となる最大地動速度を示し， $\sigma$ は対数 標準偏差である。

両者は，正規確率分布関数と対数正規確率分布関数と；地震動強さ に対する指標のとり方が異なっている。正規分布と対数正規分布では, 上限の裙野の分布が異なってくるが，合震度の評価を行う際に，デー 夕の範囲である全罗率 80\%程度までを対象とすれば, 分布形の違いに よる影響は少ない。従って, 合震度と木造家屋全壊率の被害関数は, 既往の研究との継続性を重視して, 式(1)の正規確率分布で検討を行 い, 最大地動速度との被害関数は，式(2)の対数正規確率分布で検討 を行うこととした。

用いたデータは，図 1 に示される墓石の転倒等より推定した福井地 震における最大地動速度及び合震度と, 図 3 に示される再評価された 部落毎の木造家屋の全壊率である。

\section{1 合震度 (墓石転倒震度) との関係}

図 1 (a)の福井地震における合震度と, 図 3 の木造家屋全壊率の関倸 を図 4 に示す。また, 式(1)の形で回帰された被害関数を図中実線で 示す。回帰にあたっては, 高橋 ${ }^{7}$, , 諸井・武村 ${ }^{11)}$ を参考として, 合震 度を $\Delta K=0.05$ の間隔に区切り，その区間内の全壊率を算術平均し， その区間中央值 $K$ の全壊率としたデー夕を用いて行った。これは， 平滑化の処理をすることによって，全般的な傾向を抽出しやすくする ためである。図中门が全地点のデータであり，×が平均化した值であ る。

，図 5 に，既往の検討結果である高橋 ${ }^{7)}$, 谷口・他 ${ }^{2)}$, 宮野 ${ }^{8)}$ の合震 度と木造家屋全壊率の関係と, ‘図 4 より得られた被害関数との関係を 正規確率紙上に比較して示す。また，同図には，参考のために，諸 井・武村 ${ }^{11}$ による兵庫県南部地震の合震度と全壊率の関係も示す。 本研究で得られた $K_{0}=0.52$ は，福井地震における既往の検討結果 (高橋》: $K_{0}=0.49$, 谷口・他 ${ }^{8}: K_{0}=0.42$, 宮野 ${ }^{8}: K_{0}=0.48$ ) と比べると 若干高くなっている。これは，本検討での被害関数が構造的被災度判 定 ${ }^{22)}$ に基づいており，既往の被害関数に比べ判定基準がきつくなつ ていることに起因しているものと考えられる。また, 兵庫県南部地震 の結果 $\left(K_{0}=0.70\right)$ と比べると， $K_{0}$ は, 0.7 倍程度小さくなってい る。

\section{2 最大地動速度との関係}

次に, 最大地動速度と木造家屋全壊率の関係について検討する。図 1 (b)に示す墓石転倒調查の行われている各地点で, 各地点での最大地
動速度の推定範囲と; 図 3 に示す当該部落での木造家屋全壊率との関 係を図 6 に示す。図中のが前述した最大地動速度の上限推定値であり， ○が最大地動速度の下限推定值である。これは, 墓石の形状により単 体が転倒する最大地動速度の下限値を推定する Ishiyama の式 ${ }^{13)}$ を用 いて，転倒した墓石から，その地点で少なくともこれ以上の值はあっ たという下限最大地動速度と，衝撃的な最大地動速度で転倒条件を決 めた Mallet の評価式 ${ }^{3)}$ を用いて，転倒しなかうた墓石から，これよ りは小さな最大地動速度であったという上限值を推定した結果を範囲 で示したものである.4)。

さらに，同論文 ${ }^{4)}$ では，墓石転倒率の記述のある墓地，または，墓 地周辺における木造家屋の滑り等墓石以外の被害より最大地動速度の 推定できた地点において，墓石の転倒から推定された最大速度が上限 值に近いか, 下限値に近いかを周辺の被害状況より考察し, 領域每で の概略最大速度值を推定している。このように判断された領域のデー 夕（図中×印）のみを用いて式(2)で回帰を行なった。図中実線にて 被害関数を示す。なお, 得られた $V_{0}$ は $84 \mathrm{~cm} / \mathrm{s}$ あり, 自然対数標準 偏差 $\sigma$ は 0.42 である。

図 7 に, 1995 年兵庫県南部地震でのデータに基づき, 構造被害に着 目した 1978 年以前の木造家屋の倒壊に関する被害関数 ${ }^{9)}$ と本研究で 得られた福井地震における木造家屋の全壊率の関係を正規確率紙上で 比較して示す。兵庫県南部地震における全壊率 $50 \%$ を气える最大地動 速度は $126 \mathrm{~cm} / \mathrm{s}$ であり, 福井地震では $84 \mathrm{~cm} / \mathrm{s}$ である。両者の間には 1.5 倍程度の差があり; 福井地震当時における木造家屋群の平均的な 耐震性は, 兵庫県南部地震の時のそれと比較して, 小さい傾向にあっ たことを示している。福井地震の全壊率 30\%を与える地震動の強さは, 兵庫県南部地震での全壊率 10\%を与えるものに対応する。このことは, 墓石転倒震度と全壊率の関係を検討した諸井・武村 ${ }^{11}$ の指摘と一致 しており, 合震度のみならず, 最大地動速度においてもこの関係が成 立つことを示している。

\section{3．地震動強さの分布の特徵}

得られた木造家屋の全壊率と地震動強さの被害関数より，木造家屋 の全壊率分布に基づいて福井地震における地震動強さの面的な分布の 推定を行う。

図. 8 に推定された地震動強さの分布図を示す。同図に示されるコン ターは, 図 3 に示される各部落の全壊率を, 前節でもとめた被害関数 により逆算することで各部落位置の地震動強さを推定し, 図.1の結果 も参考にしながら目視により引いたものである。なお, 同図には，参 考のため, 震央位置 ${ }^{14)}$ と地表面の亀裂を示している。図 8(b)の最大 地動速度分布図には, 全壊率 $100 \%$ 部落位置及びその最大地動速度, 墓石の転倒から推定された最大地動速度も示している。全壊率 $100 \%$ の部落は, 被害関数から地震動強さを逆算するごとはできないため, 全壊率 98～99\%程度として逆算すると, 最大地動速度としては 197〜 $223 \mathrm{~cm} / \mathrm{s}$, 合震度は $0.71 \sim 0.73$ となる。従って, 本論文では, 全壊 率 $100 \%$ 部落における地震動強さとして, 最大地動速度的 $200 \mathrm{~cm} / \mathrm{s}$ ないしそれ以上，合震度 0.7 ないしそれ以上あったものとして考えた。 分布図によれば, ‘福井平野の中央部において, 合震度 0.6 以上, 最 大地動速度 $120 \mathrm{~cm} / \mathrm{s}$ 以上であり, 中央部の他にも, 福井平野南東縁部 及び北潟湖周辺部にも地震動の強い領域が見られる。最大地動速度 $120 \mathrm{~cm} / \mathrm{s}$ 以上の領域をより詳細に見ると, 丸岡付近に, 墓石の転倒か 


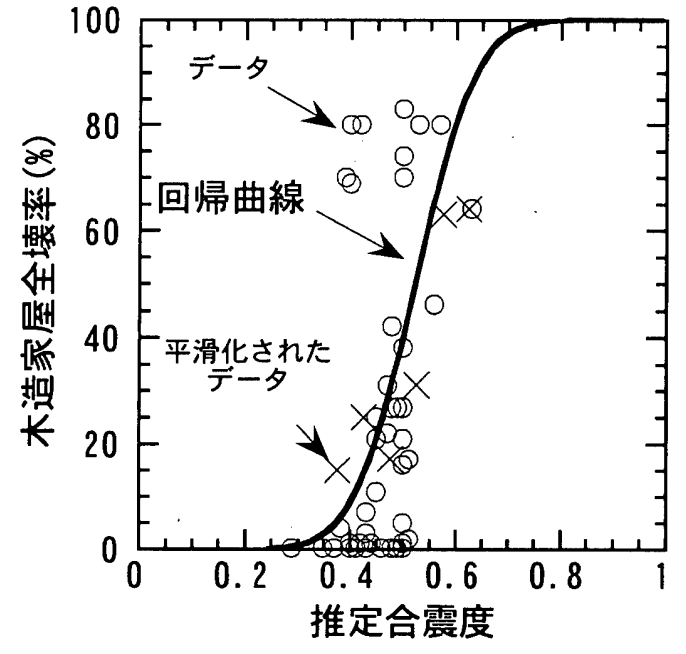

図 4 木造家屋の全壊率と推定合震度の被害関数

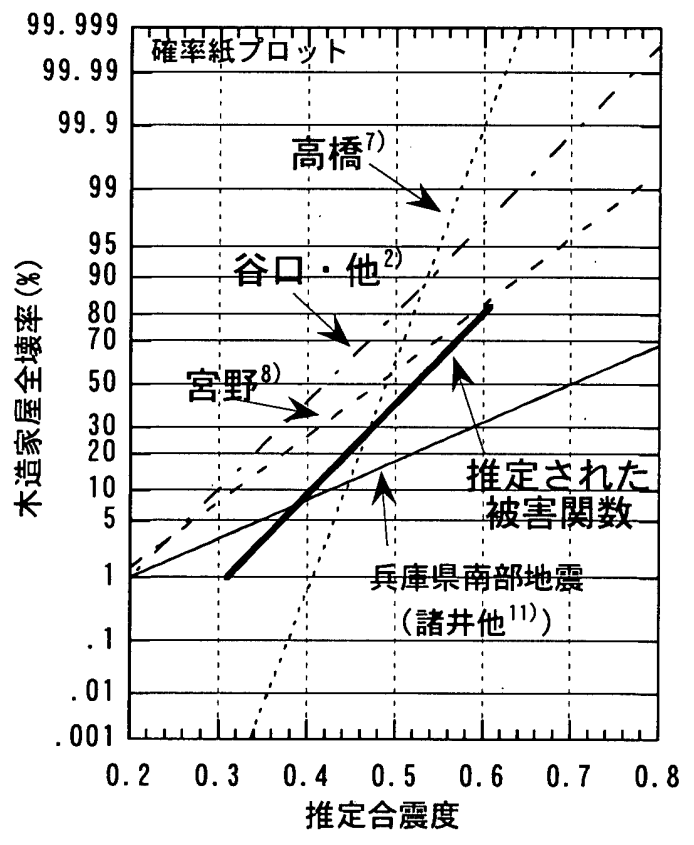

図 5 木造家屋の全壊率と推定合震度の関係

ら推定された最大地動速度 $150 \mathrm{~cm} / \mathrm{s}$ 程度の領域が福井平野東縁部に見 られる。さらに，その領域から，北西にかけて，全壊率が $100 \%$ 部 落が存在し, その推定最大地動速度は $200 \mathrm{~cm} / \mathrm{s}$ ないしそれ以上の地点 が見られる。 $200 \mathrm{~cm} / \mathrm{s}$ ないしそれ以上の領域の推定は，その基となる 竹山・他の調査 ${ }^{12)}$ が, 平野周縁部に限られているため, その分布を 詳細に議論することは難しいが， ○で示したように丸岡町から芦原町 にかけて存在し, 震央位置 ${ }^{14)}$ から北北西にかけての最大地動速度は かなり大きくなっていたものと推測される。この理由として, 震央位 置から断層北縁方向にかけて大きくなっていることより, Near-Fault

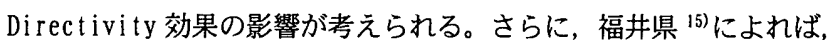
福井平野の北西部にむけて, 軟弱地盤の染さが梁くなっており, 表層 地盤の増幅効果の影響も考えられ，両者の相乗効果によるもの之推察 される。

このように, 得られた最大速度の分布は, 図 2 で推定された最大速 度の分布に比べ, 福井平野内での地震動強さの分布がより明らかにな

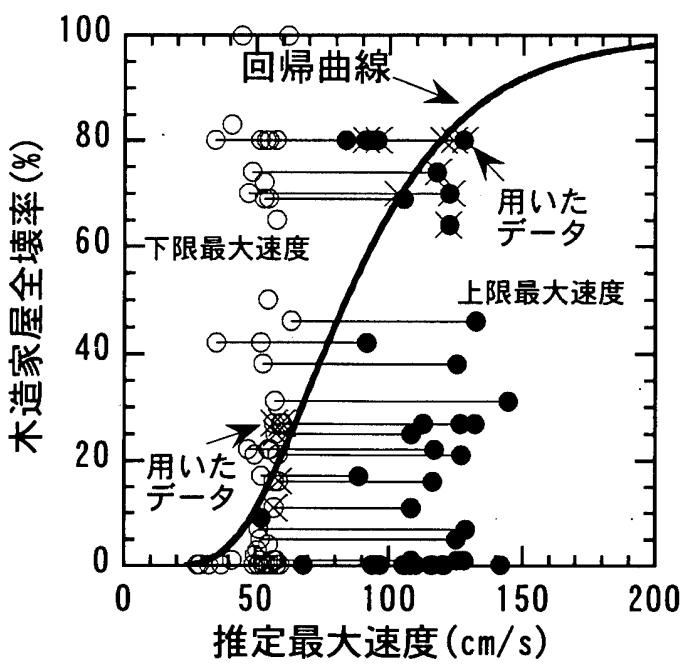

図 6 木造家屋の全罗率と推定最大速度の被害関数

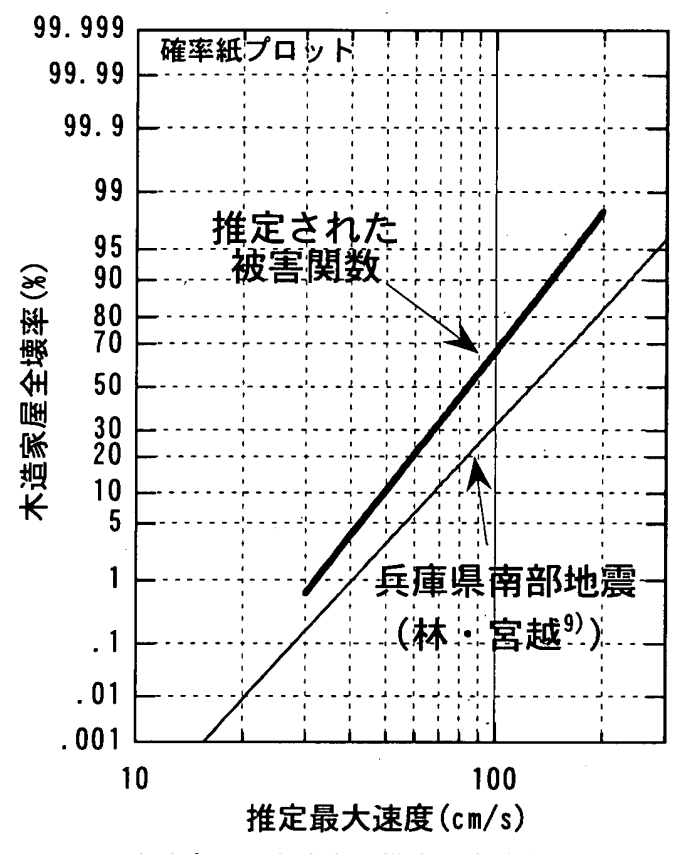

図 7 木造家屋の全壊率と推定最大速度の関係

ってきたものと考えられる。しかしながら，平野中央部の領域で， $120 \mathrm{~cm} / \mathrm{s}$ 以上の分布がどのようになっているのか等, 不確定な部分も 残うている。平野中心部における部落の全壊率は，その多くの部落の 統計資料が全壊の定義が曖昧な䍜災調査に基づいており，定義の明瞭 な構造被災度の調査である竹山・他の調査 ${ }^{12)}$ 結果を基に修正を施し ている。このとき，䍜災被災度である全壊率 100\%の部落は，構造的

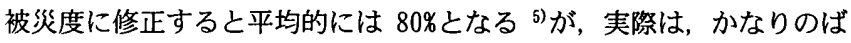
らつきを有しており，単純に全壊率 80\%で頭打ちにすることで，激震 地内の地震動強さの推定する分解能を下げてしまっている。このよう な激震地内におけるより詳細な地震動強さの分布に関しては, 今後, シミュレーション解析を加えて検討を加える必要があるものと考えら れる。

\section{4. 既往の距離減衰式に基づく地震動強さとの比較}

木造家屋の全壊率から推定した福井地震の地震動強さと, 既往の地 


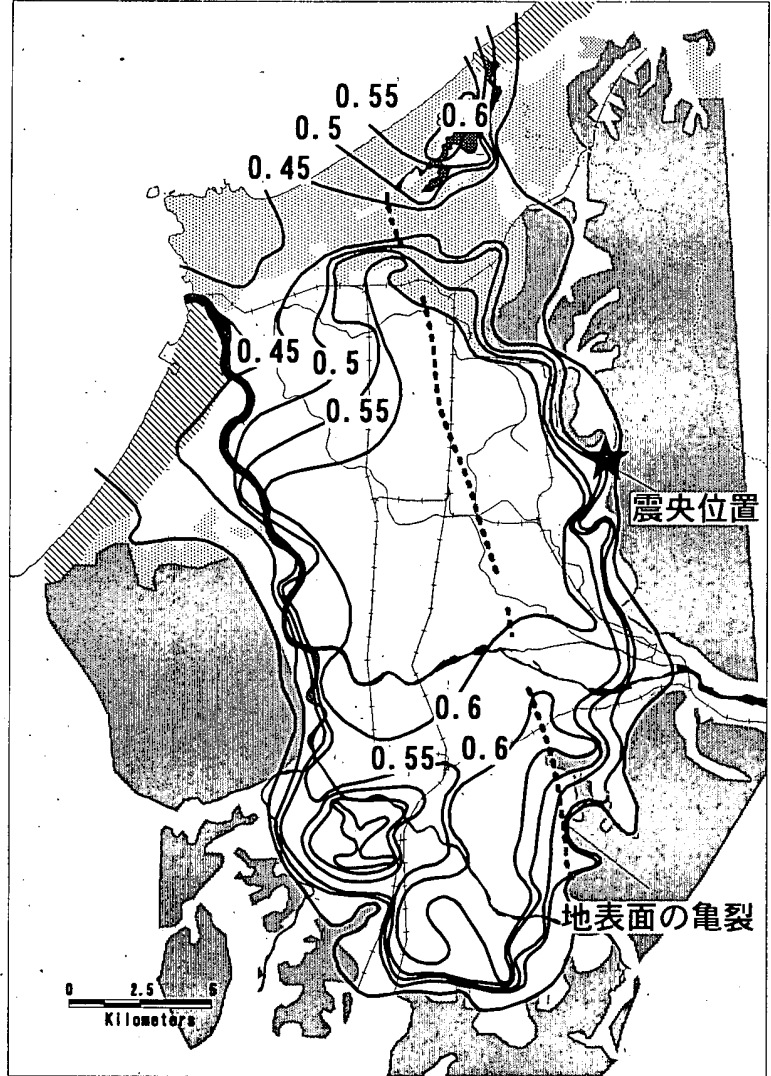

(a) 合震度

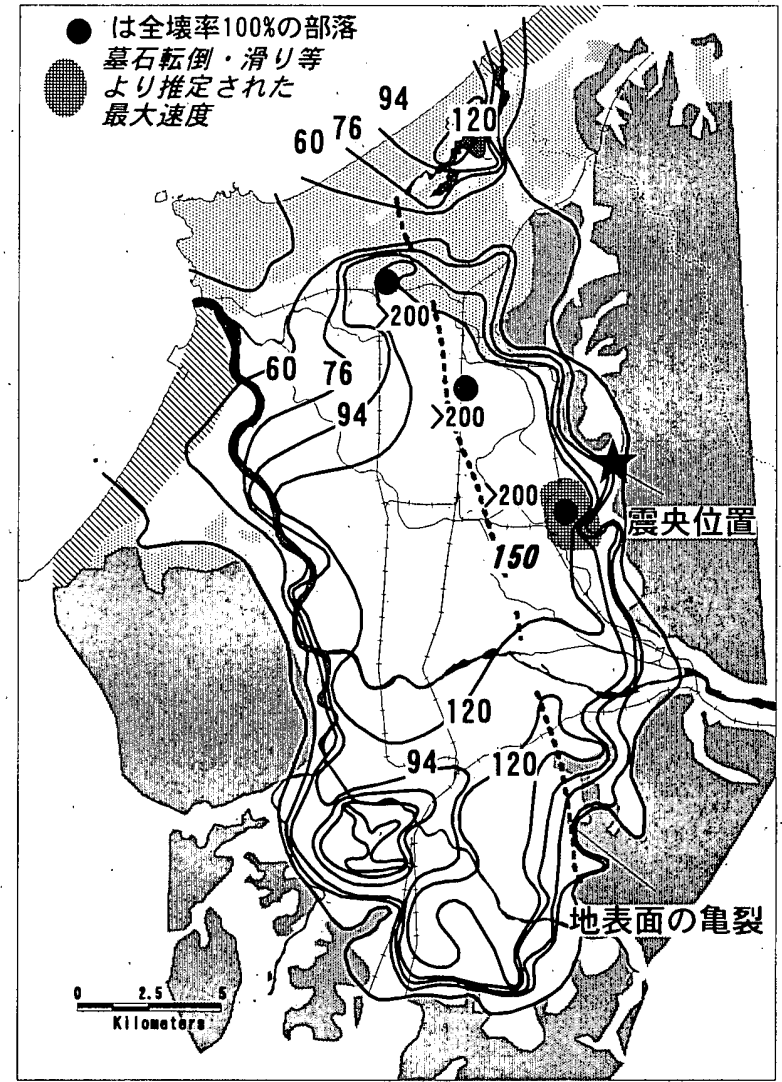

(b) 最大速度 $(\mathrm{cm} / \mathrm{s})$

図 8 木造家屋の全壊率等から推定された福井地震の地震動強さ

震動強さの予測式に基づく地震動強さとの関係について検討する。各 部落每の修正全壊率を基に, 2 で示した被害関数より, 各部落毎の地 震動強さを推定し, 吉岡 ${ }^{16)}$ の断層モデルを基に断層最短距離毎に点 でプロットしたものが図 9 である。部落毎の全壊率から地震動強さを 推定する際, 全壊率 0\%の部落は $1 \%$ とし, 修正を行っていない建研 1 次調查の全壊率 $100 \%$ 部落は $99 \%$ として計算を行っている。前述した ように，激震地区内における殆どの部落の全壊率は䍜災被災度に基づ く全壊率の定義であり，構造的被災度の全壊率に修正を施したため， $100 \%$ 全壊率が $80 \%$ となり, 合震度 0.6 , 最大地動速度 $120 \mathrm{~cm} / \mathrm{s}$ で頭 打ちになっている。

既往の地震動強さの予測式として, 司・翠川 ${ }^{17)}$ の地款内地震での 距離減衰式を用いる。なお, 本検討においては, 霞源深さを $5 \mathrm{~km}$ とし, マグニチュード $\mathbf{M}_{\text {は }} 7$ とした。

図 9(a)の実線が距離減衰式によりもとまる最大加速度レベル，点 線がその $\pm \sigma$ を示す。同図の縦軸は, 被害から推定した地震動強さの 場合は合震度, 距離减衰式から推定された地震動強さは最大加速度と なっている。合震度は, 最大加速度に対して, 墓石形状に応じたロー パスフィルターを施した值であることが指摘されている 13318)19)。既往

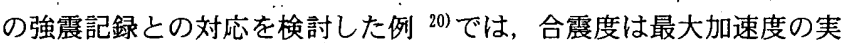
効值 $1 / \sqrt{2}$ に匹敵するされている。また, 2000 年鳥取県西部地震の軟 質地盤での例をみると, 米子で合震度 0.29 , 米子での強震記録の最 大加速度は, $\mathrm{k}$-net で $0.38 \mathrm{~g}$, 測候所で $0.28 \mathrm{~g}$, 境港では合震度 0.33 , であり, 近傍の港湾事務所の強震記録では $0.3 \mathrm{~g}$ である。これら軟質 地盤での観測記録では，前述の実効值 $1 / \sqrt{2}$ よりは大きな值となって いる。以上より，概略的ではあるが，軟質地盤で周期が長ければ，合
霞度は, 最大加速度の 0.8 程度と考えても大きな過ちは犯していない ものと考えられる。このことを考慮すると，断層最短距離 $2 \sim 10 \mathrm{~km}$ 程 度の距離減衰式で推定される最大加速度 $0.5 \sim 0.6 \mathrm{~g}$ 程度と, 合震度か ら推定される最大加速度は，ほぼ同程度となり，福井地震における最 大加速度は M7 クラスの地震の平均的なレベルであったことが推察さ れる。

図 9 (b)に最大速度の関係を示す。最大速度に関する距離隇衰式は,

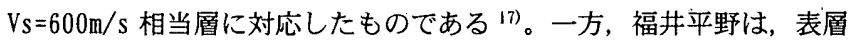
に軟弱層が堆積しており, 最大速度に関しては, その影響が無視でき ないものと考えられる。そこで, 福井平野の平均的な表層地盤として, 福井土木事務所の PS 検首結果 ${ }^{211}$ を参考とし, 深さ $30 \mathrm{~m}$ の平均 $\mathrm{S}$ 波速 度を $V s=200 \mathrm{~m} / \mathrm{s}$ と仮定し, 平均 $S$ 波速度から最大速度の増幅率 ${ }^{22)}$ もとめると 2 倍となる。図中, 細実線が $V s=600 \mathrm{~m} / \mathrm{s}$ 相当層の最大速度 であり：太実線がその増幅率を考虑した地表面での最大速度である。 ここで, 点線は, 地表面最大速度に対する $\pm \sigma$ を示す。全体的な地震 動レベルとしては, M7 クラスの平均的な地震動レベルに対応してい ることがわかるが, 合震度の場合と比較すると, 部落毎にばらつきが 大きい。その原因として, 同図においては, 部落毎の地盤の差を考慮 していないことが影響している。また, 福井平野内でも, 表層地盤は, 磞質，砂質，泥質と堆積物が異なり，局所的な増幅特性の違いが考え られる。

断層最短距離にして $7 \mathrm{~km}$ 以内の幾つかの部落で, 距離减衰式による 最大速度レベルを上回り, +10 より大きいレベル程度の部落も存在 する。この原因として，前述したように，福井平野における軟弱な堆 積層による影響及び Near-Faul t Directivi.ty 効果の影響が考えられ 


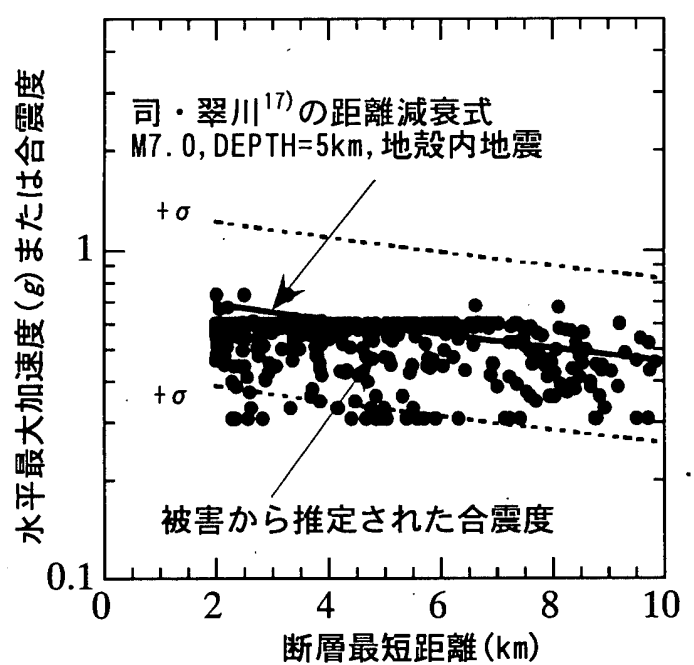

(a) 最大加速度

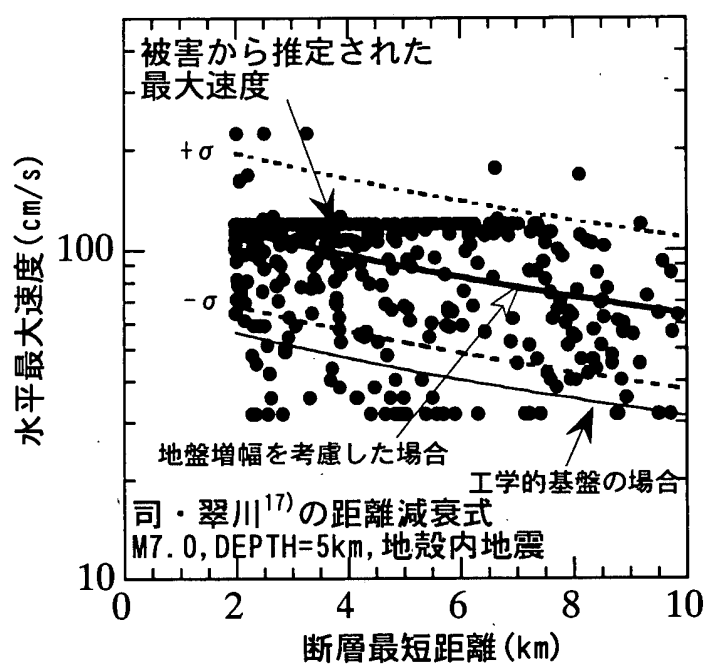

(b) 最大速度

図 9 福井地震における被害から推定された地震動強さと既往の距離減衰式より推定される地霞動強さとの関係

る。これらの部落では, かなり大きな最大地動速度であったものと考 えられる。

\section{5. まとめ}

福井地震における震源近傍での地震動強さの面的分布を評価するた めには，現存する被害デー夕を有効に活用することが重要である。本 論文では，限られた地点から評価された概略的な地震動強さの面的な 分布を補完すべく, 福井平野内ほぼ全域にわたり存在する木造家屋の 被害デー夕に着目し，当時の木造家屋の被害関数を推定することで, 地震動強さの面的な分布の評価を行った。その結果，

1）福井地震における木造家屋全壊率の被害関数は, 兵庫県南部地震 時に推定された被害関数に比べ，平均値は小さな結果が得られた。 最大速度における被害関数は, 合震度に関する既往の指摘 ${ }^{11)}$ と同様 に, 福井地震での全壊率 $30 \%$ 領域が, 兵庫県南部地震では $10 \% に$ 相当することを示した。

2）木造家屋の被害分布を用いて地震動強さの面的な分布を推定した ところ, 福井平野で最も地震動が強かった領域は, 震央から北北西 に向けて延びた地域があること, 北潟湖周辺部および福井平野南東 縁部にも強い地震動を受けた領域が存在すること等, 概略的な地震 動強さの推定した既往の結果に比べ, より詳紏な分布が得られるこ とを示した。

3）福井地震における震源近傍での地震動強さは, 高被害領域におい て合震度で 0.6 , 最大速度 $120 \mathrm{~cm} / \mathrm{s}$ 以上となり, 構造的被災度で判 定された全壊率が $100 \%$ となる一部の地点では $200 \mathrm{~cm} / \mathrm{s}$ ないしそれ 以上となることを示した。これらの推定結果を, 既往の強震動予測 式から推定される地震動レベルと比較し, 福井地震における震源近 傍の平均的な最大地動加速度, 最大地動速度は, 概ね M7 クラスの 平均的な地震動強さであることを示した。

\section{謝辞}

査読者の丁寧な意見は本論の改善に有益でした。記して感謝の意を 表します。
参考文献

1）入倉孝次郎，釜江克宏 : 1948 年福井地震の強震動 一ハイブリッド法による 広周期帯域強震動の再現一, 地震 第 2 輯 第 52 巻 第 1 号, pp.129-150, 1999

2）谷口忠，小林啓美，坂井辰郎 : 物体の転倒建造物の倒壊より推察した福井地 震の地動, 昭和 23 年福井地震震害調查報告書 II 建築部門, 北陸震災調查 特別委員会, pp. 23-29, 1951

3）末広重二, 久本壮一,田中康裕：福井地震踏查報告 (1), 昭和 23 年 6 月 23 日福 井地震調查概報，験震時報第 14 巻別冊，中央気象台, pp. 22-37, 1948

4）野畑有秀, 翠川三郎 : 被害資料から推定した 1948 年福井地震での地震動強さ, 日本建築学会構造系論文集，第 532 号，pp. 57-64，2000

5）野畑有秀, '翠川三郎, 宮村攝三 : 1948 年福井地震における木造家屋の被害分 布の再検討，地域安全学会論文集，No. 2, pp. 179-186，2000

6）物部長穗：土木工事震害調查報告, 震災予防調查会報告, 100, pp. 1-66, 1926

7) 高橋龍太郎 : 福井地震概説, 北陸震災調査特別委員会 : 昭和 23 年福井地震震 害調查報告 II 建築部門, pp. 1-21，1951

8）宮野道雄 : 墓石の転倒および木造建物の被害に基づく地動加速度に関する研 究，東京都立大学学位論文，133pp., 1984

9）林康裕, 宮腰淳一：兵庫県南部地震による被害率曲線, 1998 年日本建築学会 災害部門パネルディスカッション資料, 地震動の特性と建築物の被害一経験 と予測-，pp. 15-20, 1998

10）村尾修，山崎文雄 : 構造・建築年を考慮した建物被害デー夕に基づく灌区の 地震動分布の再推定, 日本建築学会構造系論文集, 第 523 号, pp. 141-148, 1999

11) 諸井孝文, 武村雅之: 1995 年兵庫県南部地震による気象庁震度と住家全壊率 の関係, 地震第 2 輯, 第 52 巻, pp.11-24, 1999

12）竹山謙三郎, 竹之内清次, 大崎順彦ほか：福井平野周辺部における被害率分 布について，昭和 23 年福井地震霞害調查報告書，II 建築部門，北陸震災調 查特別委員会, pp. 23-29, 1951

13) Y. Ishiyama : Criteria for 0verturning of Bodies by Earthquake Excitations，日本建築学会論文報告集，No. 317，pp. 1-13，1982

14）浜田信生 : 地震月報別冊 6 号震源カタログの部分修正について, 地震第 2 輯, 第 43 巻, pp. 307-310, 1990

15) 福井県 : 福井県地震被害想定調查, pp. 49-61, 1989

16) 吉岡直人：地震の発生機構と地款変動及び津波, 東京大学理学系研究科地球 物理学専門課程修士論文, 1974

17）司 宏俊, 翠川三郎 : 断層タイブ及び地盤条件を考慮した最大加速度・最大速 度の距離減衰式，日本建築学会構造系論文集，№. 523，pp.63-70，1999

18）望月利男, 小林計代 : 単体の運動から地動加速度を推定するための研究 単 体の動的挙動の解析，日本建築学会論文報告集，№, 248, pp. 63-70，1986

19）宮野道雄 : 墓石・木造建物被害等による震度に関する若干の検討, 土木学会 論文報告集, 第 319 号, pp. 33-42, 1982

20）表俊一郎，三宅昭春, 楢橋秀衛 : 大地震時の震央域に於ける地動最大加速度 (転倒墓石による最大加速度と強震記録との対比)，日本建築学会大会学術 講演梗概集, pp. $463-464,1979$

21) 福井県, 福井県民生活部消防防災課：福井県地震被害予測調査報告書， pp. 12-14, 1997

22) Midorikawa, S: Preliminary Analys is for Attenuation of Peak Ground Velocity on Stiff Site, Proc. of International Forkshop on Strong Motion Data, Vol.2, pp. 39-48, 1993 